\title{
CHARACTERIZATION OF HUMIC SUBSTANCE EXTRACTED FROM ANDISOLS, SPODOSOLS, PEAT, AND LIGNITE
}

\author{
Eka Rahmi*, Suwardi, and Basuki Sumawinata \\ Department of Soil Science and Land Resources Faculty of Agriculture, \\ Bogor Agricultural University, Bogor, Indonesia \\ Submitted : 2017-09-09 Accepted : 2018-03-22
}

\begin{abstract}
Soil and other materials with high C-organic content are potential natural sources of humic substances. Until now the differences in the characteristics of such humic substances that are extracted from different sources have not been widely studied. Thus, this study was aimed to characterize humic substances extracted from andisols, spodosols, peat, and lignite. The highest C-organic (48.8\%) and $\mathrm{N}$ (7.6\%) were obtained from peat and spodosols, respectively. The andisols humic substance produced the highest total acidity $\left(6.52 \mathrm{cmol} \mathrm{kg}^{-1}\right)$. Humic substance extracted from spodosols was a mostly aliphatic group and phenolate $-\mathrm{OH}$, while that of andisols and lignite contained more aromatic group and phenolate $-\mathrm{OH}$, whereas the humic substance from peat was a predominantly aliphatic group and $-\mathrm{COOH}$. The surface morphology of the humic substances observed using SEM showed varying densities and shapes due to differences in their respective degree of decomposition and the formation process involved. There has been significant interest in investigating the different characteristics of the humic substance. The type humic substances are important to be known considering of their positive effects on soil fertility and plant growth and development.
\end{abstract}

Keywords: humic substance, functional group, total acidity, surface morphology

How to Cite: Rahmi, E., Suwardi, Sumawinata, B. (2018). Characterization of Humic Substance Extracted from Andisols, Spodosols, Peat, and Lignite. Sains Tanah Journal of Soil Science and Agroclimatology, 15(1): 35-45 (doi: 10.15608/stjssa.v15i1.21622)

Permalink/DOI: http://dx.doi.org/10.15608/stjssa.v15i1.21622

\section{INTRODUCTION}

Humic substances (HS) are products of the natural decomposition of organic matter such as materials deposited in areas along water bodies, in sediments, and in the soil. These humic substances can be found in soils that contain high levels of decomposed organic matter like andisols, spodosols, peat, as well as in lignite. They possess unique characteristics that result from different degrees and duration of humification. Humification, considered to be the most important chemical process in

* Corresponding Author :

Email:eka_agronomi@yahoo.co.id geochemical transformations, is mainly involved during the early formation stage of these materials (Francioso et al., 2003). For instance, during coalification, a gradual change in the quantity and chemical composition of humic substances (Lawson \& Steward, 1989). Due to favorable properties of HS, there is a great interest in understanding the depositional fate of HS during coalification.

One factor that determines the level of humic substance content in soils is the presence of organic matter. Andisols are soils that contain considerably high organic matter content, as manifested by the existence of a thick and darkcolored top horizon (Soil Survey Staff, 2000). 
Adiwiganda, Koendadiri, \& Poeloengan (1993) reported that spodosols possess an accumulation of high organic matter content at the spodic horizon, as a consequence of leaching from the horizons above it. However, spodosols are also characterized by rough texture causing them to have low retention capacity for water and nutrient elements. Furthermore, spodosols have hardened soil layers, called fragipan and duripan (Suharta \& Yatno, 2009), which require special treatment to make them more productive.

Peat is another natural resource that contains high organic matter. This typical wetland material also holds a high utilization potential, considering that the peat ecosystem continuously produces organic acids such as humic acid and fulvic acid. However, peatland development for the purpose of sustainable agricultural and forestry management faces a number of constraints because of its unknown physical properties. Finally, another resource of high organic matter content is "young coal", or lignite. Lignite is coal (in-between bituminous coal and peat) that has gone through intensive weathering making the material excessively worn, soft, brown in color, but with low energy content. As a result, lignite cannot be efficiently utilized as an alternative source of energy; instead, it can be better used as a source of the humic substance.

Aside from the above-mentioned soils as potential sources of humic substances, young coal or "lignite" is another prospective resource as it likewise contains high organic matter. It has gone through intensive weathering, making it soft and brownish in color, however, its characteristically low energy content limits its potential use as an alternative energy source. For this reason, it is better utilized as a source of humic substance instead.

All of the afore-mentioned soils and organic materials can be tapped as rich sources of extractable humic substances. Utilization of humic substances contained in these materials is not easy, because humat substances need to be extracted first. The way extraction and the type and characteristics of the extracted material will produce different humic substances with each other. There has not been much research on this subject. Given this background, the objective of this study was to determine the characteristics of different humic substances extracted from different sources, specifically andisols, spodosols, peat, and lignite.

\section{MATERIALS AND METHODS}

This study was conducted in May to September 2016. The extraction and characterization of the humic substance were carried out at the Physical Land Resource Laboratory, Department of Soil Science and Land Resources, Faculty of Agriculture, Bogor Agricultural University. Research substances used included (1) andisols from Sukamantri, Bogor, East Java; (2) spodosols from Palangkaraya, Central Kalimantan; (3) peat from Riau, Sumatra; and (4) young coal (lignite) from Banten, West Java. The soil samples were taken from the field various locations using a composite method. To extract the humic substance, a solution of $0.1 \mathrm{~N} \mathrm{KOH}$ was used.

\section{Extraction of Humic Substance}

The humic substances were exracted from the four soil materials using the following procedure: a 50-g experimental lot was obtained from each air-dried soil sample (andisols, spodic material, peat, and lignite); each lot was placed into a 500-ml Erlenmeyer flask; each flask was added with 250-ml (0.1 N KOH) extractor solution, and shaken for 3 hours; the extract from each soil sample was sifted using a Whatman 42 paper filter; impurities at the surface of the solution were segregated from the solids; and each resulting liquid humic substance extract was prepared for analysis. 


\section{Analysis of Humic Substance Characteristics}

Each of the humic substances that were extracted from the four soil sources, as described above, was subjected to laboratory analysis in order to determine their respective attributes. The liquid humic substances were first solidified by means of freeze drying before characterization.

The key parameters analyzed were the chemical and physical characteristics of each extracted humic substance. The chemical attributes included carbon (C) content, nitrogen (N) content, $\mathrm{C} / \mathrm{N}$ ratio, carboxylate $(-\mathrm{COOH})$ group content, phenol hydroxyl (-OH) group content, functional group, and total acidity. On the other hand, the physical property analyzed was surface morphology.

The levels of $C$ content in the humic substance extracts were analyzed using Walkley and Black method. A $0.1 \mathrm{~g}$ sample of each humic substance extract was added with $30 \mathrm{ml} \mathrm{K}{ }_{2} \mathrm{Cr}_{2} \mathrm{O}_{7}$ and $60 \mathrm{ml} \mathrm{H}_{2} \mathrm{SO}_{4}$, and C-organic was determined based on the result of titration using $\mathrm{FeSO}_{4}$. Analysis for $\mathrm{N}$ was done with the Kjeldahl method, in which $0.2 \mathrm{~g}$ humic substance extract was placed inside a Kjeldahl flask, and later dissolved with $\mathrm{H}_{2} \mathrm{SO}_{4}$. Afterward, water and $\mathrm{NaOH}$ were added, and the solutions were distilled and captured with boric acid. $\mathrm{N}$ content was measured based on the result of titration with $\mathrm{HCl}$.

The determination of carboxylate group used the Ca-acetate method. This method of analysis applies the potentiometric titration approach, which is based on ion exchange. Hence, a 50 mg humic substance was extracted using $10 \mathrm{ml} 1 \mathrm{~N} \mathrm{Ca}\left(\mathrm{CH}_{3} \mathrm{COO}\right)_{2}$ added with $40 \mathrm{ml}$ distilled water, shaken and titrated with $0.1 \mathrm{~N}$ $\mathrm{NaOH}$ until the $\mathrm{pH}$ of the solution reached 9.8. Determination of total acidity used barium hydroxide method (Baryta Absorption Method), which also applies potentiometry titration, and based on the release of $\mathrm{H}^{+}$ions from the functional group. To determine total acidity, 50 $\mathrm{mg}$ of humic substance was extracted by adding $0.2 \mathrm{~N} \mathrm{Ba}(\mathrm{OH})_{2}$ to $20 \mathrm{ml}$, shaken and titrated with $0.5 \mathrm{~N} \mathrm{HCl}$ until $\mathrm{pH}$ of the solution reached 8.4. Phenol group was obtained by taking it from the resulting total acidity of the carboxylate group.

Determination of functional group was done by means of Fourier Transform Infra-Red (FTIR), while the physical surface morphology of each humic substance was obtained from the result of the Scanning Electron Microscopy (SEM). Samples for FTIR analysis should be made in the form of pellets. Preparation of pellet is done by mixing $200 \mathrm{mg} \mathrm{KBR}$ and $2 \mathrm{mg}$ of humic substances passing 50-micron filter, then inserted into tablet maker with the pressure of 800 tons for 5 minutes and 5 minutes without using pressure and also made as a control. SEM is a molecular method to better understand the form of the humic substance components which has been, until now, difficult to describe, and almost impossible to perceive. SEM shows the morphological form of the humic compound, which is quite specific to each type (Tan, 2011).

\section{RESULTS AND DISCUSSION \\ $\mathrm{C}$ and $\mathrm{N}$ Content, and $\mathrm{C} / \mathrm{N}$ Ratio}

Figure 1 shows the levels of $\mathrm{C}$ and $\mathrm{N}$ content of each of the four extracted humic substances. As shown, $\mathrm{C}$ content ranged from 25.4 to $48.8 \%$. The differences in C content are attributable to the highly variable levels of hemicellulose, cellulose and lignin content of each humic substance extract.

Persentase carbon content of the humic substance from peat was considerably higher than those of Lignite, Spodosols, and Andisols. However, the reverse was observed in the case of $\mathrm{N}$ content, with peat humic substance yielding only $1.5 \%$. High $\mathrm{C}$ content in peat humic substance can be explained by the fact that peat is at least $95 \%$ organic matter, and comes mostly from the continuous deposition of wood (stems, 
branches, roots, etc) under site conditions that prevent natural decomposition. Polak (1975) reported that tropical peat consists largely of wood materials, which are made up of over $60 \%$ lignin, and only $11 \%$ cellulose, hemicellulose, and protein. Organic matter that contains a high proportion of lignin or other decay-resistant materials generally yields a high $\mathrm{C} / \mathrm{N}$ ratio and implies that the impeded process of natural decomposition takes a very long time.

Figure 1 also illustrates that the humic substance from andisols produced the lowest $C$ content. At the same time, it yielded a high $\mathrm{N}$ content resulting in a low $\mathrm{C} / \mathrm{N}$ ratio. According to Tan (1998), the process of humification in andisols is advance. This is due to the fact that andisols were formed during the quaternary period with sand tuff structure rendering soil develop ent to proceed over a very long period of time (Tan, 1984) thus, resulting in its low carbon content.

C content of humic substances Spodosols and lignite were not very different, ie 35.6 and
$37.3 \%$, respectively. Spodosols has a high accumulation of organic matter at the spodic horizon, as a result of biocycling in the layers above it. Such organic matter accumulation in the spodosols layer at the study site Palangkaraya, Central Kalimantan was caused by the dominant presence of native vegetation such as needlegrass, Kayu gronggang (Cratoxylum sp), Kayu kurun, Kayu tuwih (Diospyros sp), ferns, and other lesser plants whose decomposed organic remains have accumulated at the higher horizon, with mean rainfall of $2000-2300 \mathrm{~mm}$ year $^{-1}$ thereby, bringing about active leaching. This phenomenon has come about because, like clay, organic matter also goes through movement from higher to lower horizons (Buurman \& Jongmans, 2002). The $C$ content of the lignite humic substance $(37.3 \%)$ was accounted for by its origin which is young coal, or of incomplete coal development, that typically yields a soft and fragile substance, brownish color, with high humidity hence, yielding a much lower carbon content.

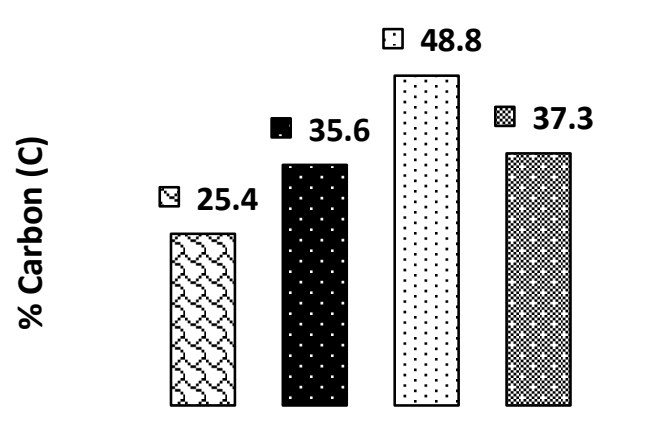

Materials

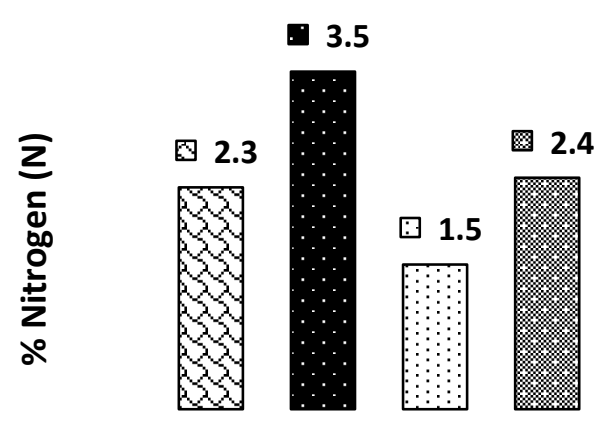

Materials

Figure 1. $\mathrm{C}$ and $\mathrm{N}$ levels, in the humic substances extracted from H1 (Andisols), H2 (Spodosols), H3 (Peat), H4 (Lignite). 


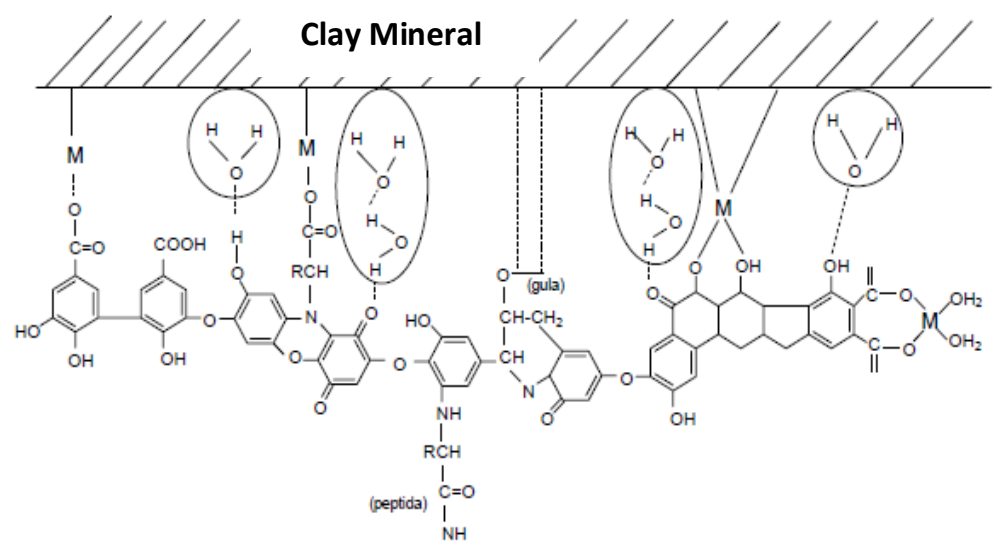

Figure 2. The model interaction metal, clay and humic acid in soil (Stevenson, 1982)

Table 1. Percentage of ash content from humic substance

\begin{tabular}{ccc}
\hline No & Materials & Ash content (\%) \\
\hline 1 & Andisols & 36.77 \\
2 & Spodosols & 34.01 \\
3 & Peat & 23.34 \\
4 & Lignite & 31.50 \\
\hline
\end{tabular}

According to Tan (2011), C levels in humic acids are generally very high, ranging from 41 to $57 \%$ however, in this study, relatively lower Ccontents were observed $25.4-48.8 \%$. This could have been due to the presence of inorganic impurities like aluminum silicates in the extracted humic substances, as no purification step was done in this study. This observation was bolstered by the findings on ash yield for each humic substances, as shown in Table 1.

Table 1 clearly shows that the extracted humic substances in this study (without purification) produced much higher ash yield compared to ash content on humic acids with purification, as obtained by (Alimin, Santosa, \&
Table 2. Value of $\mathrm{C} / \mathrm{N}$ ratio of the humic substance extracted

\begin{tabular}{ccc}
\hline No & Materials & C/N Ratio (\%) \\
\hline 1 & Andisols & 11.04 \\
2 & Spodosols & 10.17 \\
3 & Peat & 32.53 \\
4 & Lignite & 15.54 \\
\hline
\end{tabular}

Noegrohati, 2005), which was only $3.0 \%$. They also reported that during the purification stage, there occurred a separation of clay and metals from the humic acid, thereby resulting in the considerable decrease in ash yield. It should be noted that, in nature, humic acid can interact with inorganic substances such as clay and metals and form a clay-metal humic acid complex like the one depicted in Figure 2.

All four extracted humic substances exhibited high $\mathrm{C} / \mathrm{N}$ ratios, with that of peat humic substance giving the highest value (32.5), as shown in Table 2. As stated earlier, a high $\mathrm{C} / \mathrm{N}$ ratio indicates that the humic substance is relatively resistant to microbe degradation.

Table 3. Carboxyl Group Content, Total Acidity, and Phenolic Group of Humic Substances

\begin{tabular}{cccc}
\hline \multirow{2}{*}{ Materials } & Carboxyl Group & Phenolic Group & Total Acidity \\
\cline { 2 - 4 } & \multicolumn{3}{c}{ cmol kg $^{-1}$} \\
\hline Andisols & 2.60 & 3.92 & 6.52 \\
Spodosols & 2.22 & 2.89 & 5.11 \\
Peat & 3.56 & 2.95 & 6.42 \\
Lignite & 2.98 & 3.23 & 6.12 \\
\hline
\end{tabular}




\section{Total Acidity, Carboxyl (-COOH) Group, and Phenolate (-OH) Group}

Table 3 shows that the humic substance from spodosols contained the lowest carboxylate group, followed by Andisols and lignite humic substance, whereas, peat humic substance yielded the highest carboxylate group. It can also be observed that the $-\mathrm{COOH}\left(3.56 \mathrm{cmol} \mathrm{kg}^{-1}\right)$ of the peat humic substance was relatively higher than its $-\mathrm{OH}\left(2.95 \mathrm{cmol}^{\mathrm{kg}^{-1}}\right)$. This means that the peat humic substance came from protracted biodegradation of lignin. According to Stevenson (1982), during the formation of humic acid, the $\mathrm{COOH}$ group in the humic acid is the outcome of side chain oxidation of lignin such as $-\mathrm{CH}_{2} \mathrm{OH}$. Alternatively, the $-\mathrm{COOH}$ group can also come as a result of the separation of the aromatic ring component of lignin. In this regard, Polak (1975) noted that peat generally contains more than $60 \%$ lignin, and the balance is other constituents.

Given the above points, it can be stated the peat humic substance, like the one produced in this study, was the result of protracted biodegradation of lignin, considering that it is predominantly $-\mathrm{COOH}$ group. This inference is backed up by the infrared spectrum data, as depicted in Figure 3, confirming that peat humic substance tends to be mostly - $-\mathrm{COOH}$ group. This is made apparent by the appearance of absorption peaks at wavelength $3446.79 \mathrm{~cm}^{-1}$, and at $1718.58 \mathrm{~cm}^{-1}$, which can be interpreted to mean stretching vibration of $-\mathrm{OH}$

from $-\mathrm{COOH}$, and stretching vibration of $-\mathrm{C}=\mathrm{C}$ from $-\mathrm{COOH}$, respectively.

Total acidity of the humic substances comes from the combination of carboxylate functional group $(-\mathrm{COOH})$ and phenolic hydroxyl acidity, with carboxylate functional group playing a more dominant role. It is essential to know the value of total acidity because it can be used as an index of negative charge or cation exchange capacity (CEC) (Biyantoro, Subagiono, \& Sumarsono, 2006). The value of total acidity originates from the cumulative total of the carboxylate functional group $(-\mathrm{COOH})$ and the phenolic hydroxyl (weakly acidic hydroxyl group) components. High total acidity reflects a high level of complexity, or high chelating capacity, from humic compound (Tan, 1998).

Total acidity of humic acid is caused by the presence of protons that can be dissociated, or by the release of $\mathrm{H}^{+}$ions, at the carboxylate group and phenolate hydroxyl group. Referring again to Table 3, it can be seen that the values of total acidity of humic substance from spodosols and that of lignite were not very different, at 5.11 and $6.12 \mathrm{cmol} \mathrm{kg}^{-1}$, respectively while the humic substance from andisols displayed the highest total acidity value $\left(6.52 \mathrm{cmol} \mathrm{kg}^{-1}\right)$, followed by peat humic substance $\left(6.42 \mathrm{cmol} \mathrm{kg}^{-1}\right)$. The high total acidity in andisols humic substance was probably caused by the immobilization of organic matter through chelating with $\mathrm{Al}$ and allophane, as well as the formation of mineral colloids that were more stable.

Total acidity in lignite humic substance $\left(6.12 \mathrm{cmol} \mathrm{kg}^{-1}\right)$ was attributable to the more dominant phenol group $\left(3.23 \mathrm{cmol} \mathrm{kg}{ }^{-1}\right)$ compared to the carboxylate group $(2.98 \mathrm{cmol}$ $\mathrm{kg}^{-1}$ ). Rahmawati (2003) pointed out that phenol group is characteristically more stable, and not easily differentiated from $-\mathrm{COOH}$ group. This makes total acidity in lignite humic substance more stable. The presence of phenolate $-\mathrm{OH}$ functional group and- $\mathrm{COOH}$ group, which contain high oxygen levels in the humic substance, can lead to the formation of a more stable complex with metal ions thereby, causing great complex formation or high chelating capacity. This was corroborated by the result of the infrared spectrophotometry showing that there is an interaction between humic substance and metal as depicted by the appearance of absorption peaks at a wavelength of about $1382.96 \mathrm{~cm}^{-1}$ which represents symmetrical stretching vibration of $-\mathrm{COO}^{-}$anion. Further, high acidity level is also considered very important in the chemical reactivity in the soil. 
Total acidity in lignite humic substance (6.12 $\mathrm{cmol} \mathrm{kg}^{-1}$ ) was attributable to the more dominant phenolate group $\left(3.23 \mathrm{cmol} \mathrm{kg}{ }^{-1}\right)$ compared to the carboxylate group $(2.98 \mathrm{cmol}$ $\mathrm{kg}^{-1}$ ). Rahmawati (2003) pointed out that phenolate group is characteristically more stable, and not easily differentiated from $-\mathrm{COOH}$ group. This makes total acidity in lignite humic substance to be also more stable. The presence of phenolate $-\mathrm{OH}$ functional group and- $\mathrm{COOH}$ group, which contain high oxygen levels in the humic substance, can lead to the formation of a more stable complex with metal ions, thereby causing great complex formation or high chelating capacity. This was corroborated by the result of the FTIR showing that there is an interaction between humic substance and metal as depicted by the appearance of absorption peaks at a wavelength of about $1382.96 \mathrm{~cm}^{-1}$ which represents symmetrical stretching vibration of $-\mathrm{COO}^{-}$anion. Further, high acidity level is also considered very important in the chemical reactivity in the soil.

\section{Functional Group from FTIR Results}

The spectrum results of the FTIR analysis of humic substances illustrate the distribution of functional group (Figure 3), and portray the characteristics of the respective humic substance. The patterns of absorption peaks yielded by FTIR analysis that came out of the 4 humic substance samples show nearly similar spectrums, and at the same time, exhibit different wavelength vibrations. The FTIR curves describing the sample humic substances display similar absorption peaks at least 4 times, namely: primary absorption peaks at $3446.79 \mathrm{~cm}^{-1}$, $2920.23 \mathrm{~cm}^{-1}, 1382.96 \mathrm{~cm}^{-1}$, and at $1031.92 \mathrm{~cm}^{-1}$. This characteristic of absorption peaks is consistent with the findings of some earlier researcher like those of Chen, Senesi, \& Schnitzer (1978); Muzakky, Taftazani, \& Sukirno (2013); and Ricca, Federico, Astori, \& Gallo (1993).

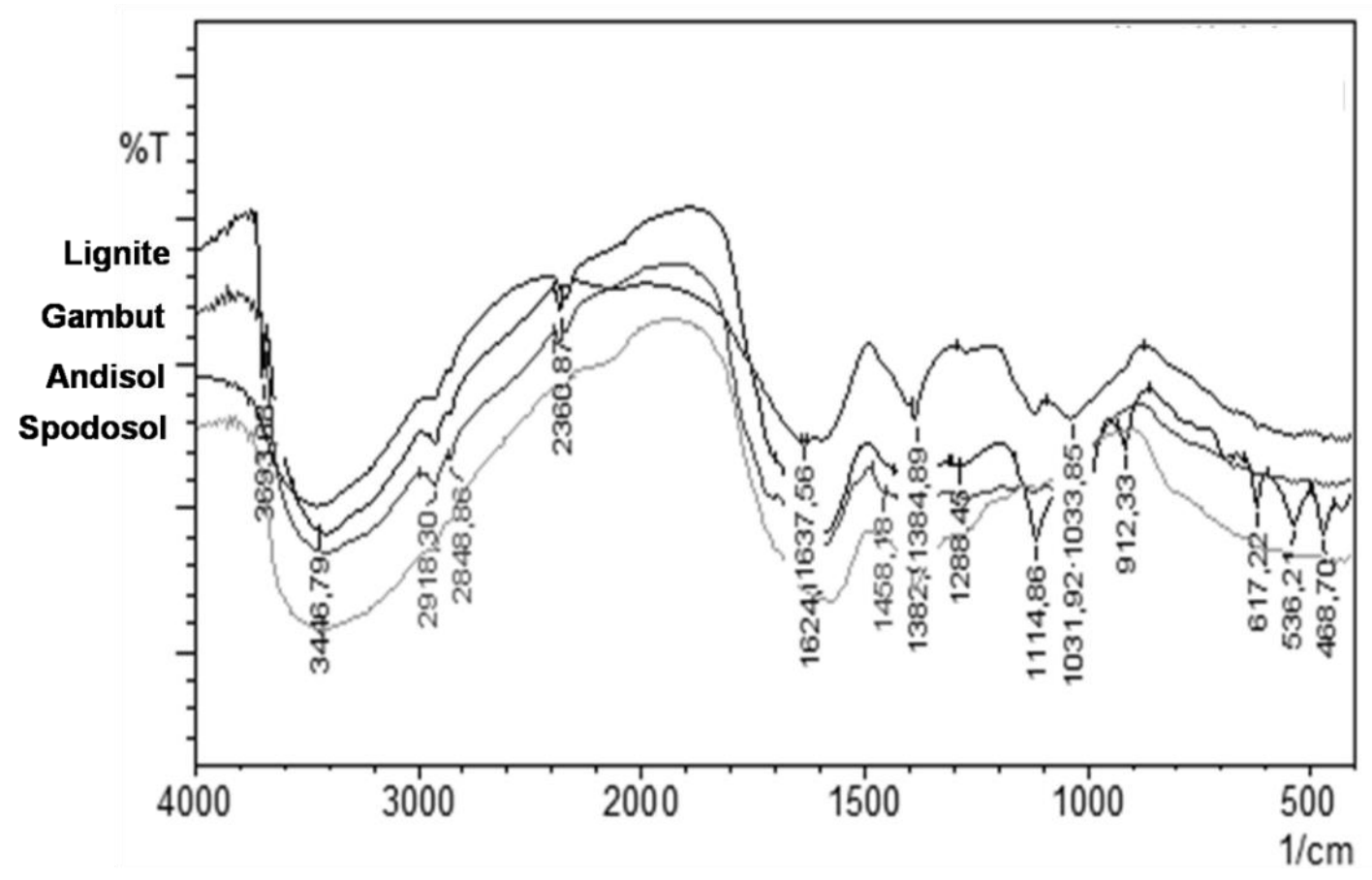

Figure 3. Spectral FTIR of humic substances from lignite, peat, andisols, and spodosols 
The wavelength figure of $1718.58 \mathrm{~cm}^{-1}$ appears only at peat humic substance indicating stretching vibration of $\mathrm{C}-\mathrm{O}$ from $-\mathrm{COOH}$ group. This figure is slightly lower than that of isolated carboxylate group $\left(1720 \mathrm{~cm}^{-1}\right)$. The absence of absorption peaks in the humic substances from Andisols, Spodosols, and Lignite can be observed at wavelength $1720 \mathrm{~cm}^{-1}$, but also appears at wavelengths $1637.56 \mathrm{~cm}^{-1}$ (Andisols), 1654.92 $\mathrm{cm}^{-1}$ (Spodosols), and $1624.06 \mathrm{~cm}^{-1}$ (Lignite) which represent an aromatic $-\mathrm{C}=\mathrm{C}^{-}$stretching vibration, and an asymmetrical stretching vibration in -COO-.

Invisibility peaks are visible at wavelength $1718.58 \mathrm{~cm}^{-1}$ which are a stretching vibration of $-\mathrm{C}=\mathrm{O}$ from $-\mathrm{COOH}$ at infrared spectrum for humic substances from andisols, spodosols, and lignite (Figure 1). This is likely the result of the interaction between - $\mathrm{COOH}$ group with metal in the soil by natural means because there has been no purification of the humic substance. According to Alimin et al., (2005), the $\mathrm{H}^{+}$ions that come from the purification solution cause the metal that is bound to - $\mathrm{COO}$ anions from $\mathrm{COOH}$ group to be dissolved because it is exchanged by $\mathrm{H}^{+}$ions, and ultimately forms $\mathrm{COOH}$. An interesting observation on the humic substance spectrum of this experimental is the appearance of wavelength $1382.96 \mathrm{~cm}^{-1}$ indicating a symmetrical stretching vibration for -COOanions; that figure is not visible at the infrared spectrum of humic substances when purification has been done. This implies that within the humic substances without purification, carboxylate group is in an anionic form (-COO) $)^{-}$, while inside the humic substances that resulted from purification, it can be found in molecular form (-COOH). Consequently, an absorption that occurs at wavelength 1382.96 $\mathrm{cm}^{-1}$ at the spectrum of humic substance without purification, likely comes from the carboxylate group that binds various metals inside the soil. According to Stevenson (1994), if humic acid interacts with metal, absorption peaks will appear at a wavelength of around $1380 \mathrm{~cm}^{-1}$ as a symmetrical stretching vibration of $-\mathrm{COO}^{-}$ anions.

The appearance of spectrums at wavelengths $3446.79 \mathrm{~cm}^{-1}, 1718.58 \mathrm{~cm}^{-1}$, $1654.92 \mathrm{~cm}^{-1}$, and $1597.06 \mathrm{~cm}^{-1}$ above, according Noorhidayah (2015), is an indication of the presence of carboxylate group. This point is also confirmed by the data on functional group (Table 2), showing the values of the respective carboxylate group.

Alipathic or asymmetric stretching vibration of $\mathrm{C}-\mathrm{H}$ from $\mathrm{CH}_{2}$, as identified at wavelength $2920.23 \mathrm{~cm}^{-1}$, appears in all humic substances produced by extraction, but in the peat humic substance, it is bolstered by the reappearance of absorption peaks at wavelength $2850.79 \mathrm{~cm}^{-1}$ which are a stretching vibration of alipathic or symmetric $\mathrm{C}-\mathrm{H}$ from $\mathrm{CH}_{2}$, and absorption band at wavelength $1458.18 \mathrm{~cm}^{-1}$ that indicates alipathic $\mathrm{C}-\mathrm{H}$ absorption. The figures at the said wavelengths are indicators of stretching of alipathic substance. Humic substance from peat has more alipathic functional group than the other humic substances. This can be seen from the humic substances that appear three times at a wavelength that is an identifier of alipathic substance $\left(2920.23 \mathrm{~cm}^{-1}, 2850.79 \mathrm{~cm}^{-1}, 1458.18\right.$ $\left.\mathrm{cm}^{-1}\right)$. The appearance of many absorption peaks at the said wavelengths makes the peat humic substance to be more dominated by alipathic substance. Besides, the degree of high humification in the peat humic substance is thought to cause the absorption peak identifier for the alipathic group to occur more frequently in the peat humic substance.

Absorption peaks that are not described in the FTIR results of all humic substances are visible at wavelength $2360.87 \mathrm{~cm}^{-1}$. Striking differences can be observed in the FTIR result of the humic substance from lignite because numerous absorption peaks occur at the other wavelength those are not described such as 
$3693.68 \mathrm{~cm}^{-1}, 1114.86 \mathrm{~cm}^{-1}, 617.22 \mathrm{~cm}^{-1}, 536.21$ $\mathrm{cm}^{-1}$ and $468.70 \mathrm{~cm}^{-1}$. The figure at wavelength $468.70 \mathrm{~cm}^{-1}$ is considered an indication of the presence of amorphous mineral that is still strongly bound with the humic substance. Uptake peak $478 \mathrm{~cm}^{-1}$ appears as an identifier of amorphous mineral by Gustafsson, Bhattacharya, \& Karltun (1999).

Based on the interpretation of the infrared spectrum, it can be inferred that humic substances yielded by this study are expected to be dominated by $-\mathrm{COOH}$ and $-\mathrm{OH}$ groups. The prevalence of $-\mathrm{OH}$ group is indicated by absorption peaks that are very specific, namely: the appearance of absorption peaks at the wavelength of about $3446.79 \mathrm{~cm}^{-1}$ means a stretching vibration of $\mathrm{O}-\mathrm{H}$. This observation is corroborated by the appearance of figures at wavelengths $1718.58 \mathrm{~cm}^{-1}, 1624.06 \mathrm{~cm}^{-1}$ and $1288.45 \mathrm{~cm}^{-1}$ which represents stretching vibration of $\mathrm{C}-\mathrm{O}$ of $-\mathrm{COOH}$ group, and stretching vibration of $\mathrm{C}-\mathrm{O}$ and deformation of $\mathrm{OH}$ from $\mathrm{COOH}$. The result of the infrared spectroscopy of the humic substances demonstrated that alipathic structure wavelength $\left(>2000 \mathrm{~cm}^{-1}\right)$ produced absorption peaks in smaller number and lesser intensity compared to the area of wavelength $<2000 \mathrm{~cm}^{-1}$. This indicates that the humic substances are dominated more by the aromatic structure.

\section{Surface Morphology Resulting from SEM Analysis}

The analysis of surface morphology with the use of SEM shows that the size and form of constituent particles of humic substances vary widely (Figure 4). Humic substances from andisols exhibited a morphological form that appeated lamellar and granular overlapping, while the humic substance from peat displayed a tabular form that appeared layered. The morphological form of the humic substance from spodosols was lamellar and contained fibers. Humic substance from lignite is of split granular sheet form which is more amorphous compared to spodosols. Variation in the form of constituent particles of humic substances is caused by differences in the level of decomposition and the process of substance formation of the respective humic substances.
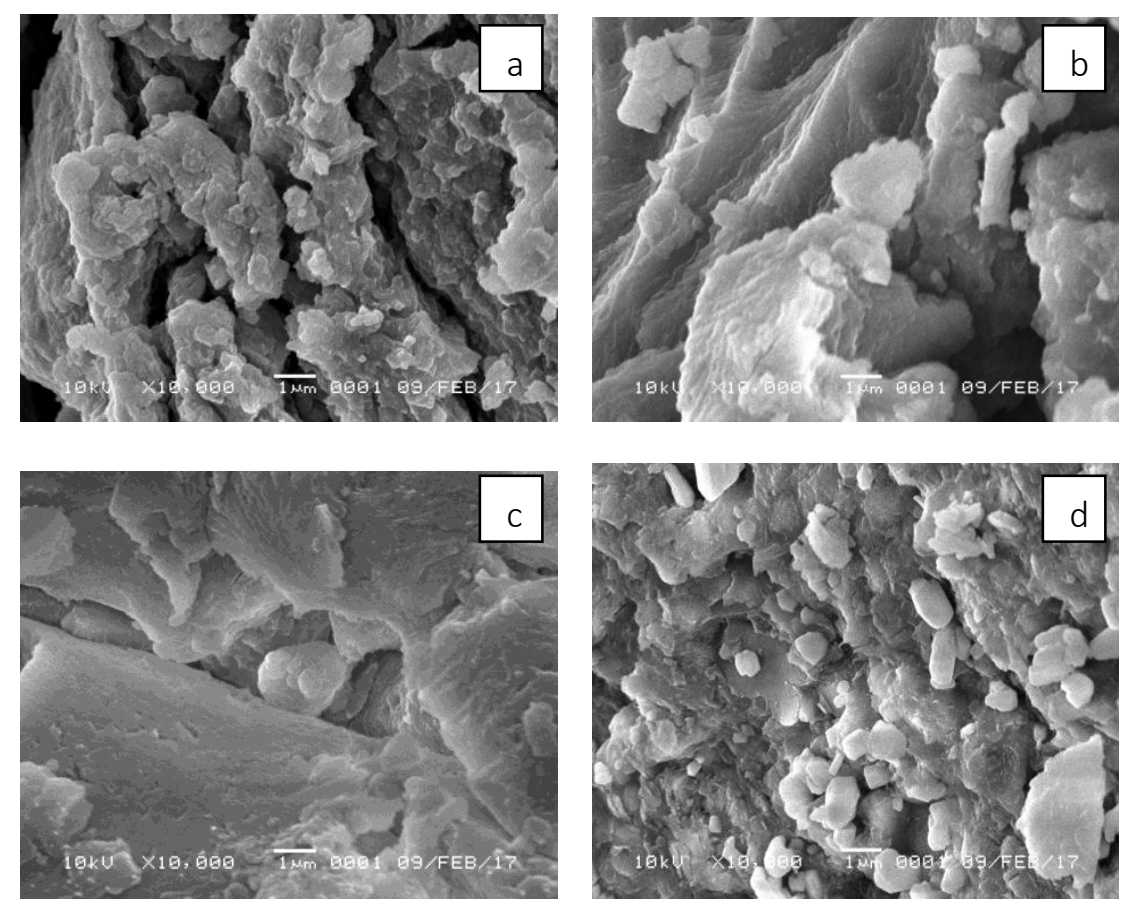

Figure 4. SEM results for humic substances from various sources (a) Andisols, (b) Spodosols, (c) Peat, and (d) Lignite.

STJSSA, ISSN p-ISSN 1412-3606 e-ISSN 2356-1424, DOI: 10.15608/stjssa.v15i1.880 
Humic acid macromolecules, as observed by (Zhou, Xu, Yang, \& Zhuang, 2014), show that $\mathrm{pH}$ value of humic acid solution plays a major role in the expansion and dispersion of humic acid molecules. The change in $\mathrm{pH}$ into alkali (12) causes a form of humic acid that is fibrous and dendritic, becoming a flat filament. The influence of $\mathrm{pH}$ can be explained by the results of the SEM of spodosols humic substance that exhibited the highest $\mathrm{pH}$ (Figure 4) in which fibers showed up in the surface, weak fibers that were produced likely because of alkaline $\mathrm{pH}$ of the spodosols humic substance.

The results of the analysis of humic substances (Figure 4) show a different appearance from that observed by Chen et al., (1978) that humic acid has a nanotube membrane like a net or beehive that shows the presence of tubular or cylindrical assembly. The membrane walls appear layered (Tan, 2011). This is because the humic substance that is produced is still very complex, and there is no purification stage from the extracted humic substance.

\section{CONCLUSION}

1. The highest $C$ content was found in the humic substance from peat, followed by lignite, spodosols, and andisols, in that order. On the other hand, the highest level of $\mathrm{N}$ content was observed in the spodosols humic substance, followed by the humic substance from andisols, lignite, and peat, in that order.

2. Highest total acidity was noted in the humic substance that was extracted from andisols, followed by those of peat, lignite, and spodosols. High total acidity was supported by carboxyl group $(-\mathrm{COOH})$ and phenolate $\mathrm{OH}$ - that reflects the complexity of humic substance.

3. The results of the above-infrared spectra interpretation can be stated that the humic substance of this study is expected to be dominated by the $-\mathrm{COOH}$ and $-\mathrm{OH}$ groups.
4. The surface morphology of humic substance that was observed with SEM showed a variable density and form that are quite different, as a result of the variation in the degree of decomposition and the respective process of humic substance formation.

\section{REFERENCES}

Adiwiganda, R., Koendadiri, A., \& Poeloengan, Z. (1993). Characteristics of spodosols at Minas geological formation. Oil Palm Research Center Bulletin, 163-173.

Alimin, N., Santosa, S., \& Noegrohati, S. (2005). Fractionation of humic acid and its influence on the solubility of zinc and cadmium ions. Journal of Basic Science, 6, 1-6.

Biyantoro, D., Subagiono, R., \& Sumarsono, M. (2006). Character of humic compound extracted from peat and andisols using methyl-isobutyl ketones. Proceedings (PPIPDIPTN) Center for Technology and Substance Process Accelerator-National Nuclear Energy Agency (BATAN), 195-204. Yogyakarta.

Buurman, P., \& Jongmans, A. G. (2002). PODZOLIZATION - AN ADDITIONAL PARADIGM. EDAFOLOGIA, 9(2), 107-114.

Chen, Y., Senesi, N., \& Schnitzer, M. (1978). Chemical and physical characteristics of humic and fulvic acids extracted from soils of the Mediterranean region. Geoderma, 20(2), 87-104.

Francioso, O., Ciavatta, C., Montecchio, D., Tugnoli, V., Sánchez-Cortés, S., \& Gessa, C. (2003). Quantitative estimation of peat, brown coal and lignite humic acids using chemical parameters, $1 \mathrm{H}-\mathrm{NMR}$ and DTA analyses. Bioresource Technology, 88(3), 189-195.

Gustafsson, J. P., Bhattacharya, P., \& Karltun, E. (1999). Mineralogy of poorly crystalline aluminium phases in the $B$ horizon of Podzols in southern Sweden. Applied Geochemistry, 14(6), 707-718. https://doi.org/10.1016/S08832927(99)00002-5

Lawson, G., \& Steward, D. (1989). Coal humic acids. New York, USA: Wiley-Interscience.

Muzakky, Taftazani, A., \& Sukirno. (2013). 
Optimasi ekstraksi asam humat dari nahumat dan karakterisasinya dengan FTIR. GANENDRA, VI(2), 15-20.

Noorhidayah, R. (2015). Chemical characteristics and infrared spectral of humic acid and fulvic acid from seven orders in Central Java and special region of Yogyakarta. Journal of Basic Science, 6, 1-6.

Polak, E. (1975). Character and Occurrence of Peat Deposits in the Malaysian Tropic. Proceeding of International Symposium on Modern Quanternary Research in Indonesia, 71-81. Rotterdam: Modern Quartenary Research in Southeast Asia.

Rahmawati, S. (2003). Characterization of humic acid from peat compost and rubber leaf compost (Research Paper). Bogor.

Ricca, G., Federico, L., Astori, C., \& Gallo, R. (1993). Structural investigations of humic acid from leonardite by spectroscopic methods and thermal analysis. Geoderma, 57(3), 263-274.

Soil Survey Staff. (2000). Keys to Soil Taxonomy. Stevenson, F. (1982). Humus Chemistry: Genesis, Composition, Reactions. New York, USA: A Willey \& Sons, Inc.

Suharta, N., \& Yatno, E. (2009). Karakteristik spodosols, kendala dan potensi penggunaannya. Jurnal Sumberdaya Lahan, 3(1), 1-14.

Tan, K. (1998). Principles of Soil Chemistry. Yogyakarta: Gadjah Mada University Press.

Tan, K. (2011). Principle of Soil Chemistry. New York, USA: CRC Press.

Zhou, S., Xu, J., Yang, G., \& Zhuang, L. (2014). Methanogenesis affected by the cooccurrence of iron(III) oxides and humic substances. FEMS Microbiology Ecology, 88(1), 107-120. https://doi.org/10.1111/1574-6941.12274 